\title{
Differences in life history features of long rough dab Hippoglossoides platessoides within Scottish waters
}

\author{
Yorgos Stratoudakis ${ }^{1,2, *}$, Robert J. Fryer ${ }^{1}$, Graham J. Pierce ${ }^{1,2}$, Robin M. Cook ${ }^{1}$ \\ ${ }^{1}$ Marine Laboratory, Victoria Road, Aberdeen AB11 9DB, Scotland, UK \\ ${ }^{2}$ University of Aberdeen, Department of Zoology, Tillydrone Avenue, Aberdeen AB24 2TZ, Scotland, UK
}

\begin{abstract}
Recent studies have shown differences in life history features of long rough dab Hippoglossoides platessoides among populations of the North Atlantic. Here, length frequency distributions from commercial catches and age information from otolith readings are used to compare long rough dab from the North Sea and the West of Scotland. Catch data from the Scottish demersal fisheries show differences in the length distribution of long rough dab between the 2 areas, with large fish $(>20 \mathrm{~cm}$ ) more prevalent in the North Sea. The maximum length of long rough dab observed in commercial catches is $8 \mathrm{~cm}$ greater in the North Sea, where otolith readings indicate that the species has a greater longevity. Growth models suggest that long rough dab of age $3+$ are significantly smaller in the West of Scotland. Potential explanations for the observed contrasts in life history features include spatial differences in temperature-related metabolic costs, food availability, sex ratios (males tend to be smaller), or age-specific loss rates (emigration or mortality). Of these, we conclude that the hypothesis involving temperature-dependent metabolic costs is the least likely explanation
\end{abstract}

KEY WORDS: Hippoglossoides platessoides - Scottish waters Length distribution $\cdot$ Longevity $\cdot$ Growth

Long rough dab Hippoglossoides platessoides is a pleuronectid of Arctic-Boreal origin that inhabits the continental shelf on both sides of the North Atlantic (Walsh 1996). Most studies on the population biology of the species come from the Northwest Atlantic (e.g. Pitt 1967, Bowering \& Brodie 1994), where long rough dab (known as American plaice in that area) has long been exploited by demersal fisheries (Walsh 1996). In a comparative study, Walsh (1994) showed that the North Sea population of long rough dab has the shortest longevity, the smallest maximum length, and the highest growth rate among all studied populations in the North Atlantic. However, Walsh (1994) used a sin-

\footnotetext{
·E-mail: stratoudy@marlab.ac.uk
}

gle source of information for the North Sea population (Ntiba 1989), and did not consider the population from the West of Scotland at all. In these areas the species is poorly studied despite its regular presence in the bycatch of demersal fisheries (Stratoudakis 1997). To our knowledge, only Bagenal (1955) has previously considered similar life history features of the long rough dab population from the West of Scotland, although his study was confined to the Clyde Sea (see Fig. 3). Here, we use age information from otolith samples and length frequency distributions from commercial catches in the North Sea and throughout the West of Scotland to compare life history features of the long rough dab populations from these 2 areas.

Material. Length frequency distributions for long rough dab discarded by demersal vessels within Scottish waters are available from the Scottish discards sampling programme (see Jermyn \& Robb 1981) between 1986 and 1993 (data from 741 trips sampled by scientific observers). We used these length frequencies as estimates of the total catch size distribution because long rough dab is not landed in Scotland. Similar data for common dab Limanda limanda were examined for comparative purposes. Common dab was selected for this comparison since it is the only other abundant flatfish whose catch size distribution can adequately be described by discards (unlike plaice Pleuronectes platessa and lemon sole Microstomus kitt, common dab is rarely landed in Scotland).

Age information was obtained by length-stratified sampling of long rough dab caught in the North Sea and the West of Scotland during 1995. The RV 'Scotia' collected samples from the northern (ICES Division IVa) and central (IVb) North Sea during the International Bottom Trawl Survey in May and August of 1995. In the West of Scotland (ICES Division VIa), samples were collected onboard commercial vessels during discards sampling in March and October. 
Methods. Annual rings from 501 whole otoliths (330 from the North Sea and 171 from the West of Scotland) were read under a binocular microscope at low magnification $(\times 20)$. An arbitrary date of birth was set for 1 March, according to information on long rough dab spawning in the northeast Atlantic (Walsh 1996). Readings on a random sub-sample of 100 otoliths were repeated and showed good reproducibility within and between readers (average percent error 4.7 and $6.4 \%$ respectively). Pitt (1967) provides evidence for the validity of age determination using otoliths from long rough dab.

A robust parameterisation of the von Bertalanffy model (Schnute 1981, Ratkowsky 1986) was used to describe the length at age of long rough dab:

$$
l(t)=I_{1}+\left(l_{2}-l_{1}\right) \frac{1-\exp \left[-k\left(t-\tau_{1}\right)\right]}{1-\exp \left[-k\left(\tau_{2}-\tau_{1}\right)\right]}
$$

where $k$ is the Brody growth coefficient, and $l_{1}$ and $l_{2}$ are the average lengths at ages $\tau_{1}$ and $\tau_{2}$ respectively. The ages $\tau_{1}$ and $\tau_{2}$ were taken to be 2 and 6 , the youngest and oldest ages sampled in all areas. Growth
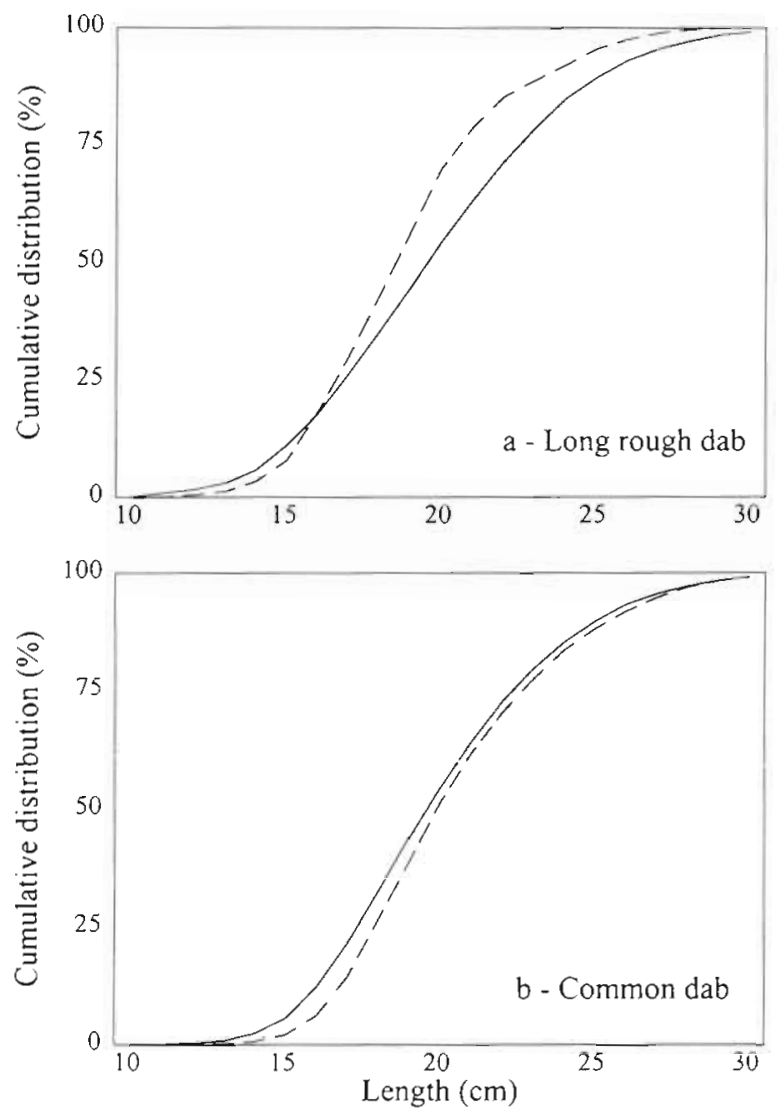

Fig. 1. Empirical cumulative distribution $(\%)$ for the catch at length of (a) long rough dab and (b) common dab in Scottish seiners and trawlers sampled in the North Sea (solid line) and

the West of Scotland (broken line) from 1986 to 1993 models were fitted to the data from the northern, central North Sea and the West of Scotland by non-linear least squares regression (Draper \& Smith 1981) and were compared with F-tests. However, care must be taken interpreting these models for 3 reasons. First, although male long rough dab are smaller than female (Bowering \& Brodie 1994), sex information was not available here, so the fitted models estimate length at age averaged over sex. Second, the commercial vessels used for otolith sampling in the West of Scotland had more selective gear than the research vessel used in the North Sea, so fewer small fish were available in the West of Scotland. Third, using length-stratified observations without incorporating information on the length distribution of the population might distort the length-age relationship for young and old fish (Castro \& Lawing 1995).

Results. Comparison of length distributions and longevity: The empirical cumulative length distribution of long rough dab catches suggests that large fish $(>20 \mathrm{~cm})$ are less frequently caught in the West of Scotland (Fig. 1a). Further, the maximum length in the catch samples from the West of Scotland is $32 \mathrm{~cm}, 8 \mathrm{~cm}$ smaller than the maximum length in the North Sea. Such differences are not evident for common dab, where the empirical cumulative distributions (Fig. 1b) and the maximum lengths of the catch $40 \mathrm{~cm}$ in both areas) are very similar.

The otolith readings reveal differences in the maximum age of long rough dab between the North Sea and the West of Scotland (Table 1). In the West of Scotland all fish were younger than age 7 , whereas in the

Table 1. Number of sampled fish (n), minimum $\left(t_{\min }\right)$ and maximum age $\left(t_{\max }\right)$ for the long rough dab otolith readings from Scottish waters (age in years)

\begin{tabular}{lccr|}
\hline Area & $\mathrm{n}$ & $t_{\min }$ & $t_{\text {max }}$ \\
\hline Northern North Sea & 173 & 1 & 10 \\
Central North Sea & 157 & 1 & 10 \\
West of Scotland & 171 & 2 & 6 \\
\hline
\end{tabular}

Table 2. Parameter estimates (and standard errors) for the von Bertalanfy growth model fitted to long rough dab data from Scottish waters: $l_{1}$ is the average length at age $2, l_{2}$ is the average length at age 6 , and $k$ is the Brody growth coefficient

\begin{tabular}{|lccc|}
\hline \multirow{2}{*}{ Area } & \multicolumn{4}{c|}{ Parameter estimates } \\
& $l_{1}(\tau=2)$ & $l_{2}(\tau=6)$ & $k$ \\
\hline Northern North Sea & $10.44(0.45)$ & $23.03(0.29)$ & $0.17(0.04)$ \\
Central North Sea & $13.59(0.55)$ & $23.37(0.29)$ & $0.08(0.05)$ \\
West of Scotland & $12.93(0.68)$ & $20.42(1.03)$ & $0.11(0.23)$ \\
\hline
\end{tabular}




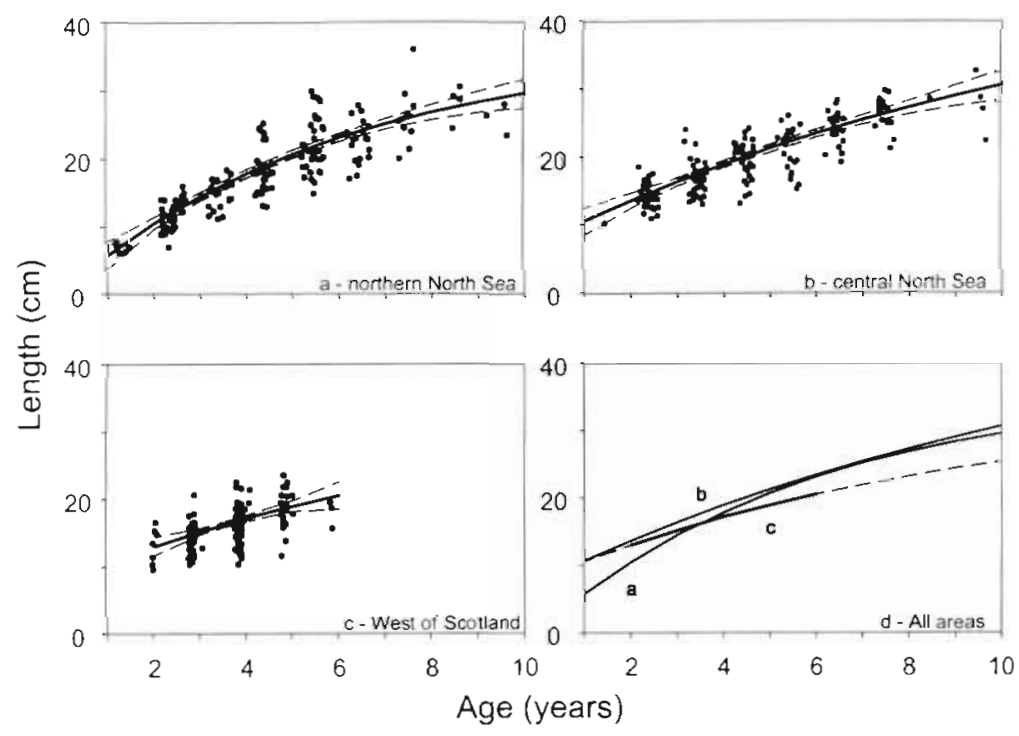

Fig. 2. Von Bertalanffy growth curves (solid lines) fitted to long rough dab data in Scottish waters: (a) northern North Sea; (b) central North Sea; (c) West of Scotland; (d) all areas. The broken lines in $(a-c)$ are pointwise $95 \%$ confidence limits for the fitted curves. The broken line in (d) is the fitted curve to the West of Scotland extrapolated beyond the ages in the sample be small. For example, note the large standard error for $k$ in the West of Scotland. This is possibly because age 1 and 2 fish were rarely sampled in the West of Scotland, since the commercial gear had a larger mesh opening than the research survey gear and allowed the escape of small fish. It should also be noted that few small fish were caught in the central North Sea. However, the same gear was used throughout the North Sea, so the reduced availability of small fish in the central North Sea is possibly due to differences in the spatial distribution of new recruits (Fig, 3).

Discussion. Our results suggest that long rough dab in the West of Scotland has shorter longevity and smaller maximum length than the North Sea population. Comparing our findings with Walsh (1994), it is clear that long rough dab in the West of Scotland has the shortest longevity and the smallest maximum
North Sea ages up to 10 yr were observed quite frequently (see also Fig. 2 for the distribution of observations at age). These results support earlier findings on the longevity of long rough dab from these areas (Bagenal 1955, Walsh 1994).

Comparison of growth: The fitted growth models are shown in Fig. 2, with parameter estimates in Table 2 . There are significant differences in growth between the 3 areas $\left(F_{6,496}=8.67\right.$, $p<0.001$ ). Differences within the North Sea appear only for long rough dab up to 3 yr old, with larger young fish in the central North Sea. For fish older than age 3 , the average length at age is significantly smaller in the West of Scotland than in the North Sea. An indication of the magnitude of these differences is provided by the fitted lengths at ages 2 and 6 , the youngest and oldest ages found in all areas (Table 2).

Despite the differences in fitted length at age, there are no significant differences in the Brody coefficient (i.e. the parameter $k$ that determines the curvature of the von Bertalanffy model) between areas (Table 2). However, the power to detect such differences might

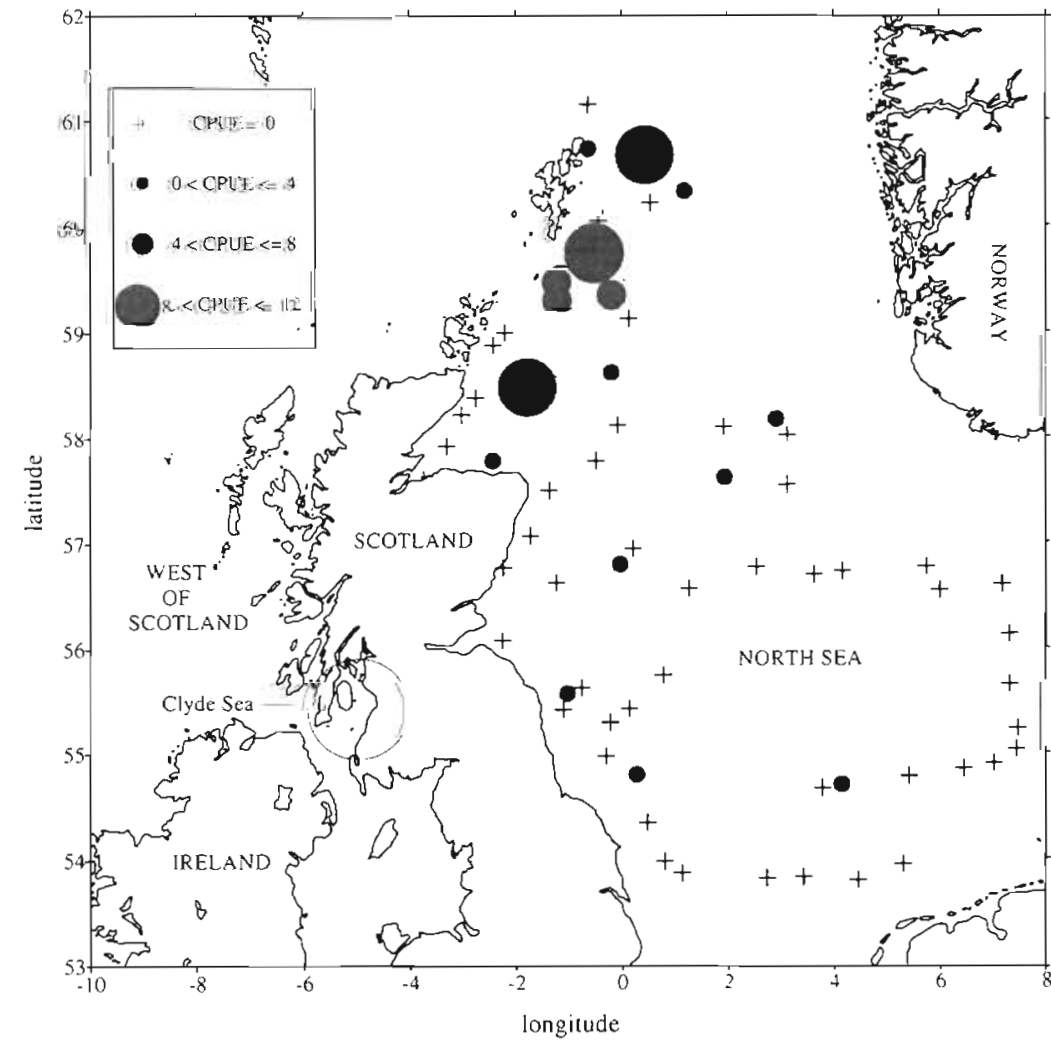

Fig. 3. Distribution and abundance of juvenile long rough dab in the North Sea (numbers of fish below $12 \mathrm{~cm} \mathrm{~h}^{-1}$ fishing, as obtained from the Scottish participation in the International Bottom Trawl Survey in May 1995). CPUE: catch per unit effort 
length among all studied populations in the North Atlantic. Temperature-mediated differences in metabolic rate have recently been put forward to explain latitudinal trends in the maximum body length and other features of long rough dab (Walsh 1994, 1996), and of flatfish in general (Pauly 1994). The average water temperature in the West of Scotland is almost $1^{\circ} \mathrm{C}$ higher than in the North Sea (Turrell \& Slesser 1992), which supports the above hypothesis. However, Pauly's hypothesis (1994) should stand for all flatfish, whereas here the difference is not apparent in common dab (Fig, 1b).

The growth models indicate that for ages $3+$, long rough dab are smaller in the West of Scotland than in the North Sea. Differences in growth would contribute to the observed disparity in the length frequencies of the commercial catches between the 2 areas (Fig. 1a). If temperature effects are negligible, spatial differences in food availability between the North Sea and the West of Scotland could provide a plausible speciesspecific mechanism for the observed patterns, since long rough dab in Scottish waters has little prey overlap with other pleuronectids (Ntiba \& Harding 1993). However, data are not currently available to evaluate this hypothesis. It could also be argued that differences in the length distributions might be due to a higher proportion of the smaller-bodied males in the West of Scotland. However, Bagenal (1955) found that less than $10 \%$ of the fish sampled in the Clyde Sea were male.

The scarcity of old fish in the West of Scotland sample suggests that mechanisms unrelated to growth could also contribute to the observed differences in the length distributions. This scarcity was also observed by Bagenal (1955), who sampled 1600 fish, none of which was longer than $30 \mathrm{~cm}$ (most $<25 \mathrm{~cm}$ ) or older than age 6 . For example, emigration or increased natural mortality for old fish could reduce the relative availability of adult long rough dab in the West of Scotland.

Acknowledgements. We thank staff from the Marine Laboraiory who helped to collect the otolith samples. Gordon Henderson provided valuable advice in otolith reading. The first

Editorial responsibility: Otto Kinne (Editor), Oldendorf/Luhe, Germany author also wishes to thank the European Union for supporting his study tinancially (Contract Nos. AIR 93/2696 and FAIR 95/6010)

\section{LITERATURE CITED}

Bagenal TB (1955) The growth rate of the long rough dab Hippoglossoides platessoides (Fabr.). J Mar Biol Assoc UK $34: 291-307$

Bowering WR, Brodie WB (1994) Distribution, age and growth, and sexual maturity of American plaice (Hippoglossoides platessoides (Fabricius)) on Flemish Cap (NAFO Division 3M). J Northwest Atl Fish Sci 16:49--61

Castro M, Lawing W (1995) A study of sampling strategies for estimating growth parameters in fish populations. Fish Res 22:59-75

Draper N, Smith H (1981) Applied regression analysis, 2nd edn. Wiley, New York

Jermyn AS, Robb AP (1981) Review of cod, haddock and whiting discarded in the North Sea by Scottish fishing vessels for the period 1975-1980. ICES CM1981/G:47

Ntiba MJ (1989) The biology and ecology of the long rough dab, Hippoglossoides platessoides (Fabricius 1780) in the North Sea. PhD thesis, University of East Anglia

Ntiba MJ, Harding D (1993) The food and the feeding habits of the long rough dab Hippoglossoides platessoides (Fabricius 1780) in the North Sea. Neth J Sea Res 31(2): $189-199$

Pauly D (1994) A framework for latitudinal comparisons of flatfish recruitment. Neth J Sea Res 32(2):107-118

Pitt TK (1967) Age and growth of American plaice (Hippoglossoides platessoides) in the Newfoundland area of the Northwest Atlantic. J Fish Res Bd Can 24:1077-1099

Ratkowsky DA (1986) Statistical properties of alternative parameterisations of the von Bertalanffy growth curve Can J Fish Aquat Sci 43:742-747

Schnute $J$ (1981) A versatile growth model with statistically stable parameters. Can J Fish Aquat Sci 38:1128-1140

Stratoudakis Y (1997) A study of fish discarded by Scottish demersal fishing vessels. $\mathrm{PhD}$ thesis, University of Aberdeen

Turrell WR, Slesser G (1992) Annual cycles of physical chemical and biological parameters in Scottish waters. Scot Fish Work Pap No. 5/92

Walsh SJ (1994) Life history traits and spawning characteristics in populations of long rough dab (American plaice) Hippoglossoides platessoides (Fabricius) in the North Atlantic. Neth J Sea Res 32(3/4):241-254

Walsh SJ (1996) Ecology, resource surveys and management of long rough dab (American plaice). Hippoglossoides platessoides, (Fabricius) in the Barents Sea and the Newfoundland-Labrador Shelf. PhD thesis, University of Bergen

Submitted: July 14, 1997; Accepted: September 22, 1997

Proofs received from author(s): October 21,1997 